\title{
A Case of Listeria monocytogenes Bacteremia Treated with Levofloxacin
}

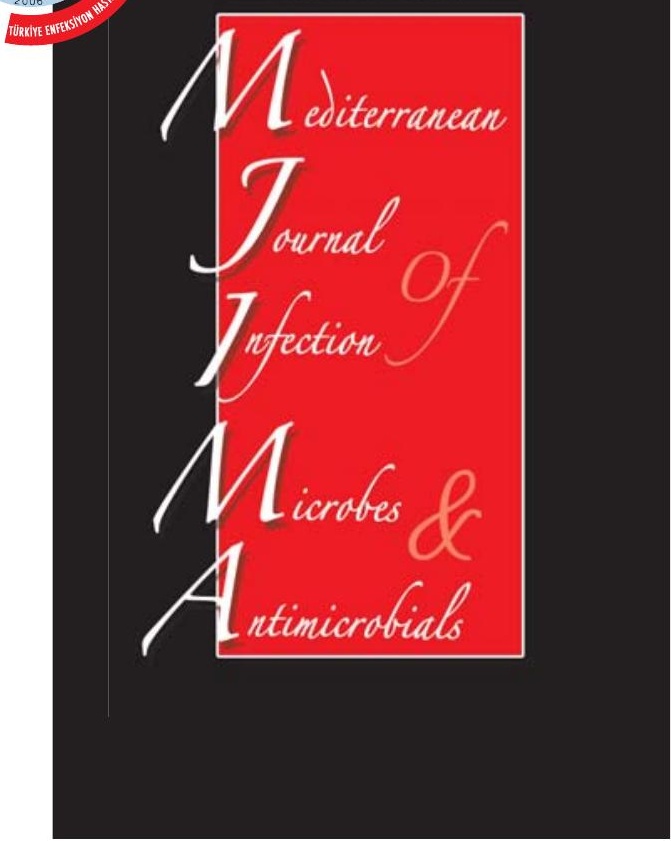

Ferit ÇELIK ${ }^{1}$, Atike Pınar ERDOĞAN² ${ }^{2}$, Şöhret AYDEMiR ${ }^{3}$, F. Rüçhan USLU², Oğuz Reşat SiPAHi ${ }^{4}$

\footnotetext{
${ }^{1}$ Ege Üniversitesi Tıp Fakültesi, İç Hastalıkları Anabilim Dalı, İzmir, Türkiye

${ }^{1}$ Department of Internal Medicine, Faculty of Medicine, Ege University, Izmir, Turkey

${ }^{2}$ Ege Üniversitesi Tıp Fakültesi, İç Hastalıkları Anabilim Dalı, Tıbbi Onkoloji Bilim Dalı, İzmir, Türkiye

${ }^{2}$ Department of Medical Oncology, Faculty of Medicine, Ege University, Izmir, Turkey

${ }^{3}$ Ege Üniversitesi Tıp Fakültesi, Tıbbi Mikrobiyoloji Anabilim Dalı, İzmir, Türkiye

${ }^{3}$ Department of Medical Microbiology, Faculty of Medicine, Ege University, Izmir, Turkey

${ }^{4}$ Ege Üniversitesi Tıp Fakültesi, Enfeksiyon Hastalıkları ve Klinik Mikrobiyoloji Anabilim Dalı, İzmir, Türkiye

${ }^{4}$ Department of Infectious Diseases and Clinical Microbiology, Faculty of Medicine, Ege University, Izmir, Turkey
}

\section{ÖZET}

Listeria monocytogenes gram-pozitif basil morfolojisinde bir bakteri olup, kontamine yiyecekler vasıtasıyla salgınlara neden olabilmektedir. Erişkinde özellikle yaşılılarda ve immünsüpresif hastalarda etken olarak karşımıza çıkabilmektedir. Kinolonlardan levofloksasinin L. monocytogenes'e in vitro etkinliği ümit verici olmakla birlikte tedavide yayınlanmış tecrübe kısıtıdır. Bu yazıda, levofloksasinle mikrobiyolojik başarı elde edilen bir kateterle ilişkili L. monocytogenes bakteremisi olgusu rapor edilmiştir. Metastatik meme karsinomu tanılı, kemoterapi sonrası tekrarlayan parasentez ihtiyacı ve şiddetli bulantı-kusmaya bağlı oral alım bozukluğu nedeniyle palyatif bakım amaçlı medikal onkoloji kliniğine yatııılan hastaya yatışının ikinci ve dördüncü gününde tekrarlayan ateş yüksekliği nedeniyle kültürleri alınarak ampirik levofloksasin 500 mg/gün başlandı. Hastanın izleminde yatışının ikinci ve dördüncü gününde alınan kateter kanı ve periferik kan kültürlerinde L. monocytogenes üremesi oldu. Levofloksasin altında ateşi gerileyen hastada levofloksasin tedavisinin üçüncü ve sekizinci günlerinde alınan kan, asit ve kateter kültürlerinde üreme olmadı. Hasta yatışının 15. gününde pulmoner emboliye bağlı olduğu düşünülen ani gelişen solunum yetmezliği nedeniyle eksitus oldu. Hastanın eksitus sonrası alınan kültürlerinde üreme olmadı. Olgumuz bildiğimiz kadarıyla levofloksasinle mikrobiyolojik başarı elde edilen ilk $L$. monocytogenes bakteremi olgusudur ve levofloksasinin; bakteremide tek başına olmasa da in vitro etkinliği ve mikrobiyolojik başarı elde edilebildiği göz önüne alındığında L. monocytogenes kurtarma tedavisinde kombinasyon için iyi bir seçenek olabileceğini düşündürmektedir.

Anahtar kelimeler: Kinolonlar, listeriyoz, levofloksasin

Geliş Tarihi: 22.06.2014 • Kabul Ediliş Tarihi: 20.10.2014 • Yayınlanma Tarihi: 25.10.2014 


\section{ABSTRACT}

Listeria monocytogenes are gram-positive bacilli causing epidemics through contagious food. It may lead to infections in the elderly and immunocompromised host. Although in vitro efficacy of levofloxacin is promising, published experience is limited. Acatheter-related L. monocytogenes bacteremia cleared microbiologically under levofloxacin is presented in this paper. A patient, diagnosed with metastatic breast carcinoma, was hospitalized for palliative care in medical oncology clinic with the recurrent need of paracentesis and impaired oral in take caused by severe nausea and vomiting. On the second and fourth days of hospitalization,the patient developed recurrent fever. Patient's cultures were performed and empirical levofloxacin $500 \mathrm{mg} / \mathrm{per}$ day was started. Cultures (on the second and fourth days of hospitalization) yielded growth of L. monocytogenes. Under levofloxacin, the patient had no fever again and cultures drawn on the third and eighth days of antibiotherapy did not yield any pathogen. The patient died due to sudden respiratory failure, which was thought to be related to pulmonary embolism on the fifteenth day of hospitalization. Blood cultures, performed on the day the patient died, did not yield any pathogen. To our knowledge, this is the first case of $L$. monocytogenes bacteremia treated successfully with levofloxacin. The case suggests that levofloxacin (although not as monotherapy) may be a good option for combinations in the salvage therapy of $L$. monocytogenes bacteremia.

Key words: Quinolones, listeriosis, levofloxacin

Received: 22.06.2014 • Accepted: 20.10.2014 • Published: 25.10.2014

\section{Gíisis}

Listeria monocytogenes gram-pozitif basil morfolojisinde bir bakteri olup, yiyecekle bulaşarak salgınlara neden olabilmektedir. Erişkinde özellikle yaşılırda ve immünsüpresif hastalarda etken olarak karşımıza çıkabilmektedir. L. monocytogenes bakteremisinde birinci tercih tedavi seçeneği ampisilin ve gentamisindir ${ }^{[1,2]}$. Buna karşı bu tedaviye yanıtsızık ya da iki ilaçtan birine allerji durumunda trimetoprim-sülfametoksazol kullanılabilir $^{[2]}$. Kinolonlardan levofloksasinin L. monocytogenes'e in vitro etkinliği ümit verici olmakla birlikte tedavide yayınlanmış tecrübe kısıtlıdır ${ }^{[1-3]}$. Bu yazıda, levofloksasin ile mikrobiyolojik başarı elde edilen bir kateterle ilişkili L. monocytogenes bakteremisi olgusu rapor edilmiştir.

\section{OLGU SUNUMU}

Kırk sekiz yaşında kadın hasta, bulantı-kusma ve oral alım bozukluğu nedeniyle Ege Üniversitesi Tıp Fakültesi Medikal Onkoloji Hastanesine yatırıldı. Hastanın öyküsünde 2008 yılından beri memede invaziv duktal karsinom tanısıyla izlendiği, neoadjuvan dört kür kemoterapi sonrası sağ modifiye radikal mastektomi ve aksiler diseksiyon ameliyatı yapıldığı öğrenildi. Patoloji sonucunda invaziv duktal karsinom olarak rapor edilen hastaya Ekim 2008 tarihinde adjuvan radyoterapi uygulanmış. Temmuz 2011 tarihinde hastada karaciğer, akciğer ve kemik metastazı saptanması üzerine, Ağustos 2011 tarihinde altı kür kemoterapi verilmiş. Yanıt alınamaması üzerine Ekim 2012 tarihinde beş kür kemoterapi daha uygulanan hasta tekrarlayan parasentez intiya$\mathrm{cı}$, bulantı-kusma ve oral alım bozukluğu nedeniyle yatırıldı. Hastanın yatışının ikinci günü ateş yüksekliği oldu. Bilinci normal olan (Glasgow koma skalası 15), fizik muayenesinde herhangi bir ateş odağı saptanmayan, ateş ve asit dışında ekstra bulgusu olmayan hasta; kan, asit örneği kateter ve kültürleri alındıktan sonra antibiyotiksiz izlenmeye devam edildi. İki gün sonra ateşi tekrarlayan hastaya kan, asit örneği ve kateter kültürleri yapıldıktan sonra ampirik olarak levofloksasin 500 mg/ gün başlandı. Hastanın izleminde yatışının ikinci ve dördüncü gününde alınan kateter kanı ve periferik kan kültürlerinde gram-pozitif basil morfolojisinde bakteri üredi. Bakteri VITEK 2 ile (Bio Meriéux Inc., Mercy L'Etoile, Fransa) L. monocytogenes olarak tanımlandı. Asit kültüründeyse üreme olmadı. Kökenin antibiyotik duyarlılığı ampisiline ve gentamisine duyarlı, trimetoprim-sülfametoksazole dirençliydi. Levofloksasin altında ateşi gerileyen hastada levofloksasin tedavisinin üçüncü ve sekizinci günlerinde alınan kan ve kateter kültürlerinde üreme olmadı. Hasta yatışının 15. gününde pulmoner emboliye bağlı olduğu düşünülen ani gelişen solunum yetmezliği nedeniyle kaybedildi. Hastanın eksitus sonrası alınan kan ve derin trakeal aspirat kültürlerinde üreme olmadı.

\section{TARTISSMA}

Listeria türleri klinikte çok sık rastlanan bir problem olmamakla birlikte, bebek ve özellikle yaşlı, immünsüprese hastalarda nispeten sık görülür. Listeriyoz veterinerler, gıda mikrobiyologları, tıbbi mikrobiyologlar ve klinisyenler için de önemli bir araştırma konusudur ${ }^{[1,2]}$.

Listeriyoz daha çok menenjit ve olgumuzda olduğu gibi bakteremi şeklinde seyretmekte, nadiren gastro- 
enterit salgınlarına da neden olabilmektedir ${ }^{[1,2]}$. Bakteremi ve menenjitte ana tedavi önerisi bu konuda randomize kontrollü ya da kontrollü herhangi bir çalışma olmamakla birlikte kökeni 1970'li yılların sonunda yapılmış bir tavşanda menenjit çalışmasının sonuçlarına dayanan ampisilin, gentamisin kombinasyonudur $^{[2,3]}$. Gentamisin sinerji yaratarak ampisilinin bakterisidal etkinliğini artırmaktadır ${ }^{[2,3]}$. Penisilin allerjisi varsa ana alternatif trimetoprim-sülfametoksazoldür ${ }^{[1,2]}$. Sefotaksim seftriakson ve seftazidim gibi sefalosporinler in vitro ve klinik olarak etkisizdir ${ }^{[2]}$.

Ampisiline rağmen hastaların yaklaşık 1/3'ünde hastalık mortal seyredebilmektedir ${ }^{[2]}$. Bu olgulardaki tedavi başarısızlığı patojenin tedaviye olan direncinden ziyade enfeksiyöz hastalığın evresine veya altta yatan hastalık nedeniyle hastanın kritik durumuna bağıdır. $\mathrm{Bu}$ nedenle sağlıklı bireylerin sağkalım olasılıkları daha yüksektir ${ }^{[2]}$.

Kinolonların L. monocytogenes'e karşı in vitro etkinliği yüksektir ${ }^{[2]}$. Levofloksasin in vitro ve makrofajlar içerisindeki $L$. monocytogenes'e karşı etkilidir ${ }^{[1]}$. On L. monocytogenes kökeni üzerinde mikrodilüsyon yöntemiyle yapılan bir çalışmada MiK $_{90}$ değerlerinin moksifloksasin için $0.12 \mathrm{mg} / \mathrm{L}$, siprofloksasin için $0.5 \mathrm{mg} / \mathrm{L}$, levofloksasin için $1 \mathrm{mg} / \mathrm{L}$ olduğu görülmüştür ${ }^{[4]}$. Levofloksasin ile $L$. monocytogenes üzerinde hayvan deneyi verisi olmamakla birlikte moksifloksasin tavşanda menenjit modelinde ampisilin ve gentamisin kombinasyonuyla eşdeğer bakteriyel etkinlikte bulunmuştur $^{[5]}$. Levofloksasin ile $L$. monocytogenes tedavisindeki klinik tecrübe kısıtlıdır. Viale ve arkadaşları meropenem ve levofloksasinle tedavi edilen bir $L$. monocytogenes olgusu bildirmişlerdir ${ }^{[6]}$. Hu ve arkadaşları levofloksasine yanıt vermeyen bir L. monocytogenes sepsisi bildirmişlerdir ${ }^{[7]}$.

Olgumuzun seyrinde ateş sonrasında, herhangi bir enfeksiyon odağı saptanmayınca ampirik olarak levofloksasin başlanmıştır. Hastada ateş yanıı alındığı ve kontrol kan kültüründe de üreme olmadığı için tedaviye aynı şekilde devam edilmiştir. Hastanın genel durumu kateterin çekilmesine uygun olmadığından ve ateş yanıtı alındığından kateteri çekilememiştir. Olgumuzun L. monocytogenes bakteremisi levofloksasin ile tedavi edilmiş, buna karşı olgu primer malignitesinin ve has- tanede yatmaya bağlı immobilizasyonun tetiklediği muhtemel pulmoner emboli sonrası gelişen solunum yetmezliğinden kaybedilmiştir.

Olgumuz bildiğimiz kadarıyla levofloksasin ile mikrobiyolojik başarı elde edilen ilk $L$. monocytogenes bakteremi olgusudur ve levofloksasinin; bakteremide tek başına olmasa da in vitro etkinliği ve mikrobiyolojik başarı elde edilebildiği göz önüne alındığında $L$. monocytogenes kurtarma tedavisinde kombinasyon için iyi bir seçenek olabileceğini düşündürmektedir.

\section{KAYNAKLAR}

1. Lorber B. Listeria monocytogenes. In: Bennett JE, Dolin $R$, Mandell GL (eds). Principles and Practice of Infectious Diseases. $7^{\text {th }}$ ed. New York: Churchill Livingstone, 2010:2707-14.

2. Hof H, Nichterlein T, Kretschmar M. Management of listeriosis. Clin Microbiol Rev 1997;10:345-57.

3. Scheld WM, Fletcher DD, Fink FN, Sande MA. Response to therapy in an experimental rabbit model of meningitis due to Listeria monocytogenes. J Infect Dis 1979;140:287-94.

4. Rolston KV, Frisbee-Hume S, LeBlanc B, Streeter $\mathrm{H}$, Ho $\mathrm{DH}$. In vitro antimicrobial activity of moxifloxacin compared to other quinolones against recent clinical bacterial isolates from hospitalized and community-based cancer patients. Diagn Microbiol Infect Dis 2003;47:441-9.

5. Sipahi OR, Turhan T, Pullukcu H, Calik Ş, Tasbakan M, Sipahi $H$, et al. Moxifloxacin versus ampicillin + gentamicin in the therapy of experimental Listeria monocytogenes meningitis. J Antimicrob Chemother 2007;61:670-3.

6. Viale P, Furlanut M, Cristini F, Cadeo B, Pavan F, Pea F. Major role of levofloxacin in the treatment of a case of Listeria monocytogenes meningitis. Diagn Microbiol Infect Dis 2007;58:137-9.

7. Hu R, Li J, Yao K, Miao M, Zhu K, Liu Z. Listeria septicemia accompanied by central nervous system involvement in a patient with multiple myeloma and secondary diabetes. Am J Case Rep 2013;14:226-9.

Yazışma Adresi /Address for Correspondence

Dr. Ferit ÇELiK

Ege Üniversitesi Tıp Fakültesi, İç Hastalıkları Anabilim Dalı Bornova, İzmir, Türkiye

E-posta: feritcelik_@hotmail.com 